\title{
Banking Sector Competition and Financial Development in Sub-Saharan Africa
}

\author{
Charles K. Ricky-Okine ${ }^{1}$, Twum Amankwaa ${ }^{2}$ and Emmanuel Anane ${ }^{3}$ \\ ${ }_{1}^{1}$ Finance Department, Universidad Empresarial de Costa Rica and Department of Procurement and Supply Science, Koforidua \\ Technical University, Ghana. \\ Email: charles.ricky@,ktu.edu.gh, charlesricky7@gmail.com \\ ${ }^{2}$ Department of Banking and Finance, All Nations University, Ghana. \\ Email:twumas122@yahoo.com \\ ${ }^{3}$ Department of Banking and Finance, All Nations University, Ghana.

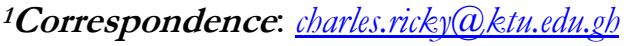

\begin{abstract}
The study sort to establishing a relationship between banking sector competition and financial development in subSaharan n Africa. The study further disaggregated the data used into Francophone and Anglophone countries, and these were examined separated and compared. Using an annual data on banks across 37 countries in Sub-Saharan Africa spanning the period 2001-2016 and employing the Fixed Effects estimation technique, the study revealed that there is a positive and significant relationship between financial development (FDCredit) and competition (CR3) for the full sample and the anglophone samples. The study further revealed that banking sector stability is essential for the financial development of both Anglophone and francophone countries within the sub-region. Macroeconomic variables did not have any impact on financial development generally except in francophone countries where exchange rates were found to have an impact on financial development. Bank-level variables such as ZSCORE, non-performing loans, profitability, liquidity and capitalization, on the hand had little impact in Anglophone countries on financial development compared to francophone countries. The study found that larger banks contribute positively to the development of the financial sector and banks tend to be bigger in Anglophone countries, and their banking sector is also more competitive than the francophone countries for the period used. Less emphasis should be placed on bank-level variables as these do not have significant impacts on the financial sector for Anglophone countries. Francophone countries should, however, control bank-level variables to ensure that they achieve greater financial development.
\end{abstract}

Keywords: Bank competition, financial development, sub-Saharan Africa

Citation: Ricky-Okine, C. K., Amankwaa, T.and Anane, E.Banking Sector Competition and Financial Development in Sub-Saharan Africa,2020; 5(3): 58-85.

Received: July 18, 2020

Accepted: September 30, 2020 


\subsection{Introduction}

In the last three decades, the financial systems of many African countries have undergone significant transformation. Before then, the financial systems of these countries were dominated by banks, many of which were foreign owned. The few domestic banks were owned either directly by the state or indirectly, through other state institutions. There were clear distinctions on the kind of activities each bank could engage in based on the license they acquired. Moreover, there were very few active capital markets on the continent. Where these existed, they were dominated by foreign firms. In the last two decades however, many African countries have had active capital markets that have slowly grown over time and some of them have even attracted large domestic capital. Also, though most countries' financial systems are still dominated by banks, these banks are mostly privately owned and there is active and growing domestic participation. There is also a widespread of the so called "universal banking license" which allows banks to engage in many activities; and some banks even sell insurance products. The insurance sector, which was almost nonexistent in the past in many countries, has begun to emerge steadily. These advances could be regarded as indications of financial development in these countries.

This, transformation has been mainly because of the completion of structural adjustment programmes that were introduced in the late 80's and early 90's. A key feature of the programmes was the liberalization of the financial sector. A key feature of the liberalization was the removal of some of the barriers to entry and a widening of the scope of financial markets. The Liberalization has led to an increase in the number of banks and the scope of the activities that these banks engage in. Along with the liberalization has come the increased focus on banking regulation (with BASEL II and III) which has centered mainly on the capitalization of banks. For instance, following BASEL III, banks in Zambia were required in 2007 to raise their minimum capital from $\$ 358,240$ to $\$ 2.2$ million (Owen \& Pereira, 2018). Commercial banks in Kenya were required in 2008 to increase their capital base from $\$ 3.3$ million to $\$ 12.5$ million by end of 2012 (Owen \& Pereira, 2018). In 2017, banks in Ghana were required to raise their minimum capital from GHS120 million (approx. \$25 million) to GHS400 million (approx. \$83million) by December, 2018.

Banking sector competition has been found to differ across countries in Africa. It can be seen that the banking sector in Nigeria and South Africa are significantly more competitive compared to Ghana and Kenya (Research Data, 2018). The financial systems in many of these countries can be regarded to be still under developed compared to countries in Europe. For instance, while bank interest rates in Ghana range from $20 \%$ to $45 \%$, it is less than $5 \%$ in the UK and other European countries.

These events have jointly contributed to a rise in the degree of competition between the banks in many countries (Hakenes \& Schnabel, 2011; Naceur \& Omran, 2011; Owen \& Pereira, 2018). At the same time, the policies and reforms that have been implemented were also targeted at accelerating the financial development process of these countries. A key argument that has been put forth by policy makers is that, the liberalization of the system and the increased capitalization of banks are necessary to build strong financial systems that are stable and capable of supporting businesses. Meanwhile, it is argued that the new capital levels are a threat to the survival of local banks; many of these banks have either been acquired, liquidated or merged with other banks. This has led to the criticism that the new capital policies are skewing competition of the industry in favour of foreign banks who often meet these requirements with much ease. This has brought to the fore a policy debate about the role of bank competition on financial sector development (Barth, Lin, Ma, Seade, \& Song, 2013; Beck, Chen, Lin, \& Song, 2012; Carbó-Valverde, Benink, Berglund, \& Wihlborg, 2015).

In recent years, there is growing interest in the factors that are responsible for the development of the financial sectors of countries. Theories on financial intermediation have argued that efficient financial intermediation have a strong positive effect on economic growth as it leads to lower cost of business financing. This has been evidenced by a large body of growing literature on the relationship between financial development and growth (King \& Levine, 1993; Laeven, Levine, \& Michalopoulos, 2015; Levine, 2004). These studies have also showed that financial development could in itself serve as a good predictor of economic growth. This is partly the reason why, in many countries, policies targeted at economic growth have been mainly focused on financial sector development. In Africa, major policy reforms were implemented in the late 1980's and early 1990's, in many countries, with the aim to revolutionize the financial sector by making the sector more liberal, stable and more diverse (Lafourcade, Isern, Mwangi, \& Brown, 2006; Quartey \& Afful-Mensah, 2014; Tchamyou \& Asongu, 2017). 
From a theoretical perspective, the existing literature has shown an unclear relationship between banking sector competition on one hand and economic growth and financial development on another hand. From one angle, conservative economic hypothesis states that the exercising market power (greater monopoly) results in less credit availability, higher interest rates (price) which are signs of minor degrees of financial development and these then result in very low growth of the economic. Other authors have also argued that in the presence of market power, banks do have an inducement to put in funds for soft information, that is, building some sort of cordial interactions with clients, which could lead to greater credit availability to businesses at lower costs (Ariccia, Laeven, \& Marquez, 2014; Porzio, Sampagnaro, \& Verdoliva, 2018; Shen, Shen, Xu, \& Bai, 2009). Thus, one view suggests that competition can enhance financial development while the other argues that competition will adversely affect financial development.

From the above, the problem necessitating this study is the fact that one factor that has received little, if any, attention is the impact that bank competition has on financial development. At best, studies exist on the correlation existing between banking competition and growth of the economic. The scarcity of research on the relationship between banking sector competition and financial development is probably due to the assumption that competition comes along with financial development. The study therefore seeks to examine this relationship separately on its own merits and goes on to find out how the correlation linking development of financial system and banking sector competition differs among Francophone and Anglophone countries

The study is in five sections. The second section talks about a review of relevant literature on banking sector competition and financial development. Furthermore, the third segment of the paper presents the model specification, the variables used, including the data source for the study. Section four of the paper discusses the econometric results. Section five discusses the conclusion made from the study and hence remarks on policies for decision making.

\subsection{Literature Review}

From the time of its inception, banks are known to play primary role in financing economies across the world. This, therefore, shows that banking competition has significant impacts on the development of economic. Primarily, a higher level of banking sector competition within the banking system is anticipated to present a number of benefits including the decline of prices of financial services, which accelerates growth and investments. In addition, a high level of banking competition ought to produce a lower monopolistic power of banks, and by that result in a decrease of banking fees. Nevertheless, a keen competition by nature should pushes banks to decrease their costs, i.e. make effective use of resources. (Hasan and Marton, 2001; Fries and Taci, 2005). In spite of the benefits of banking competition, there are literatures that suggest some likely depressing impacts of bank competition by way of extreme risk-taking of banks, which in the end hampers financial stability (Allen and Gale, 2004; Carletti and Hartmann, 2002).

It is very obvious that there are a number of theoretical and empirical studies highlighting the significance of financial developing and inclusion to stimulate economic growth in Sub-Saharan n African countries (Chauvet and Jacolin, 2017; Leon, 2015a; Ncube, 2007). Nevertheless, literature on banking competition spurring financial development is quite silent. This study, therefore, looks at the relationship between banking completion and financial development in SSA

It is very true that an efficient financial system contributes to building a continuous economic growth and hence an open energetic economic system. Literature shows that economies that have strong and developed financial institutions tend to grow more rapidly with particular references to the size of the banking system and the liquid nature of their stock markets. Both in the short and the in long run, such financial developments impact positively on economic growth.

Literature shows that the first remarkable study on the topic financial development leading and speeding economic growth has been proposed by King and Levine (1993). They used data comprising of 77 countries between the period 1960-1989 and find that a number of financial development indicators such size of formal financial intermediary division to GDP, the significance of banks in relation to the central bank, the ratio of credit issued to private firms 
relative to GDP and the percentage of credit allocated to private firms are positively and significantly correlated to real economic activity such as GDP growth, physical capital accumulation, enhancement in capital allocation.

From the backdrop of finance-growth nexus, there isn't a literature pointing to direct relationship between competition in the banking industry and economic growth of a country. However, according to Claessens and Laeven, (2005) there is current empirical evidence which seem to confirm that bank competition aids industrialisation and also helps to finance private and small firms (Cetorelli and Strahan, 2006; Giannetti and Ongena, 2005) that are seen as the engine of economic growth. This shows that, competition in the banking industry indirectly contributes to economic growth.

In their study, Levine and Zervos (1998) employed an empirical framework similar to King and Levine (1993), but they focused particularly on the links between stock market and bank credit, from one angle, and real economic activity from another angle. Using 47 countries for their analysis between 1976 and 1993, their findings indicate that when bank credit increases, it leads to an increase in real per capita income. They further said that stock markets provide diverse services from banks (i.e., both are complements not substitutes). Further works on finance-growth nexus have also used bank variables (typically, domestic or private credit) and came out with same evidence (e.g. Levine et al., 2000; Law and Singh, 2014).

In line with partial equilibrium models, Manove et al. (2001) in their study draw a model with entrepreneurs and banks (both are risk-neutral). Their findings show that, when there are a variety of banks in a competitive environment amidst asymmetric information, there is a sharp reduction in the use of collateral in debt contracts banks below its socially efficient level. They further argued that this scenario tend to lead banks in funding too many of insignificant investment projects. What this implies is that a number of bad projects are financed and hence many entrepreneurs experience liquidation. However, using collateral exemptions or using partial equity financing better promotes entrepreneurial activities including the culture of maintaining good standards with regards to investment projects.

In their study, Cetorelli and Peretto (2012) suggest a dynamic, general equilibrium model in which banks operates in a Cournot oligopoly and thereby proved that bank competition (i.e. increased number of credit firms) has an inherently unclear impact on capital accumulation. On a whole, this implies that increased number of banks lead to a high amount of credit accessible to entrepreneurs (supporting the view on benefits of competition). Again, the increased number of banks took away incentives that offered relationship services that enhance the prospects of good investment projects.

Asante, Agyapong and Anokye (2011) in their work "bank competition, stock market and economic growth in Ghana," used time series data for the period between 1992 and 2009 to investigate the relationship between bank competition, stock market and economic growth in Ghana. They found that competition in banking system and stock market development granger cause economic growth in Ghana. Again, the study revealed that competition in banking system is good for economic growth in the long run. They also found out however, that, there is an inconsistent response of economic growth to stock market development. They established the Short and long run relationship using Granger causality and the Autoregressive Distributed Lag (ARDL)/ Dynamic Ordinary Least Square (OLS) approach respectively (Asante, Agyapong and Anokye, 2011)

Mitchener and Wheelock (2013), using data on banking market concentration and manufacturing industry-level growth rates for US states to perform an analysis of the impacts of banking market structure and regulation on economic growth in the US for the period 1899-1929, found that concentration (increase in number of bank) in the banking market in general had a positive influence on manufacturing sector growth. Accordingly, this result does not agree with empirical evidences from cross-country studies' findings that concentration of banks tends to retard economic growth. (Mitchener and Wheelock, 2013)

In this paper, Bekmurodova (2016) did a comprehensive review of literature on banking competition and stability. In their review, they identified main variables used to measure banking competition including market structure variables, contestability variables, inter industry variables, institutional variables and macro-economic condition variables. They also reviewed two schools of thoughts on bank competition which include competition fragility and competition stability theories. The study revealed some major measures of bank competition; HHI, Lerner index, Boone indicator and Z-score. The findings of the study focused on executives of banks and government officials who are concerned with improving the social well-fare of stakeholders. 
Ngongang (2015) examine the relationship between financial development and economic growth in sub-Saharan $\mathrm{n}$ Africa. The study observed 21 Sub-Saharan n African (SSA) countries and employed the dynamic panel GMM technique to estimate the relationship between the variables. From the study conducted, it was evident that there exists a positive and significant relationship between financial development and economic growth. However, the study further revealed that financial liberalization has negative and insignificant effects on growth rate of real GDP of SSA countries. This according to the study is the fact that one- third of the SSA countries in the data sample did not embark on the process of financial openness.

Pruteanu-Podpiera, Weill, Schobert (2007) used exhaustive quarterly data for Czech banks and examine causality between bank competition and efficiency at the firm level in Czech Republic by employing Granger-causality-type analysis. The also study examined the relationship between competition and efficiency. The study initially measured the level and the evolution of banking competition between 1994 and 2005 using the Lerner index on the loan market, by with data on loan prices and revealed that there is no development in banking competition all through the transition period. Second, we investigate the relationship and the causality between competition and efficiency. The study also found a negative causality which runs from competition to efficiency. The study concluded that the relationship between bank competition and efficiency in the banking sector of the Czech Republic is negative and unidirectional.

\subsection{Methodology}

The research focuses on the specification of the model used for the study with emphasis on the Fixed Effects estimation technique. The Fixed Effects estimation is selected to tackle any potential endogeneity problems that may be inherent in the data which was used to estimate the model specified for the study. It also treats the consequences of omitted variable bias and has better identification characteristics(Cameron \& Trivedi, 2009; Hegre, Oneal, \& Russett, 2010; Ivanovic, 2016). This study is experimental and quantitative. The main results are estimated using linear time series techniques following previous studies on economic growth. Consistent with this design, robustness tests are performed to determine whether the estimates obtained are efficient and consistent and to ensure that the conclusions are valid.

3.1 research methods

The research methods employed in this study have been explained under the following sub-titles: data and data source, definition and measurement of variables, and measurement of bank liquidity

\subsection{Data and Data Source}

Annual data on banks across 37 countries in Sub-Saharan Africa spanning the period 2001-2016 was used for the study. This data was obtained from two main sources, BankScope and the World Development Indicators of the World Bank for all years. These sources are deemed to be the most reliable and comprehensive source for macroeconomic and bank-level data on African countries and banks in Africa.

\subsection{Definition and Measurement of Variables}

3.3.1 Financial Development (FD)

Different measures of financial development are used. These consisted of both bank-based and stock market-based measures. These are described below.

3.3.2 Domestic credit to private sector by financial sector as a ratio of GDP (FDCredit)

Domestic credit to by financial sectors refers to financial resources provided to the private sector by financial corporations, such as through loans, purchases of non-equity securities, trade credits and other accounts receivables that establish a claim for repayment. The financial establishments include economic authorities and deposit money banks, along with other financial institutions such as leasing companies, moneylenders, insurance corporations, pension funds, and foreign exchange companies (Demirguc-Kunt et.al, 2015). This proxy or indicator captures the essence of domestic asset distribution within an economy.

3.3.3 Broad money to GDP ratio (BM)

Broad money is the sum of currency outside banks; demand deposits other than those of the central government; the time, savings, and foreign currency deposits of resident sectors other than the central government (World Bank, 2015). It measures the degree of monetization of an economy and as such has been employed as a standard measure of financial development in many studies, of which includes that of King and Levine (1993b); Murinde and Eng (1994); Lyons and Murinde (1994); Odhiambo (2004).

\subsubsection{Competition}

We measure bank competition using the concentration ratio (ElBannan, 2015; Sarkar \& Sensarma, 2016). Because some countries have very few banks in the data, we used a three-bank concentration ratio (CR3) as in Sarkar \& 
Sensarma (2016). The three-bank concentration ratio represents the total market share of the three biggest banks. That is the proportion of the market that is controlled by the three biggest banks. Thus, the CR3 measures the portion of total bank assets owned by the three biggest banks. A higher ratio signals a weak competition in the market since this will imply that few banks constitute the majority of industry assets.

\subsubsection{Bank stability}

It is believed that bank stability is an essential factor in explaining financial development (Apanga, Appiah, \& Arthur, 2016; Maredza, 2015; Sarkar \& Sensarma, 2016). It is plausible to argue that, when banks are stable, they will contribute positively to the development of the financial sector(Beck, De Jonghe, \& Schepens, 2013; Carvallo \& Pagliacci, 2016). This study measures bank stability using $z$-score. The Z-score has been used by previous authors to explain banking and financial sector phenomena such as default risk and insolvency. Default risk here refers to the likelihood that a given bank will be able to repay its debtors. It is argued that if a bank cannot repay its debtors, then it will become insolvent and its debtors will take over its assets. Thus, a bank that has high default risk or insolvency risk, it will be considered as being unstable. The z-score is expressed as (ROA+CAP)/ $\sigma \mathrm{ROA}$, where $\sigma \mathrm{ROA}$ is the standard deviation of the rate of return on assets. A higher z-score is desirable as it represents more stability or higher capacity to repay debtors. Also, considering the $\log$ will make it easier to interpret and reduce the possibility of heteroscedasticity by lowering the absolute size of the observations and converting them into percentages (Bhagat, Bolton, \& Lu, 2015).

\subsubsection{Credit Risk}

In one breath, financial development is fundamentally about making the financial sector and its services more accessible and cheaper to access and encouraging more people to participate in the sector(Mayordomo \& RodríguezMoreno, 2018; Zulkhibri, 2015). Borrowers play a crucial role in ensuring this, and it includes paying off their loans and on time. If borrowers default on their loans, it increases the risk premium banks place on lending rates and this will adversely affect the goal of financial development. This study captures this using the credit risk as measured by the non-performing loans ratio (NPLR). This ratio measures the stock of loans that are nonperforming compared with the total loan stock at a given point in time (Angkinand \& Wihlborg, 2010; Boudriga, Boulila Taktak, \& Jellouli, 2009). A loan is classified as being non-performing if the interest and or principal have been overdue for more than 90days(Kuranchie-Pong, Bokpin, \& Andoh, 2016; Were \& Wambua, 2014). The NPLR is thus computed by expressing overdue loans as a ratio of total loans outstanding, that is, NPL/Total loans outstanding.

\subsubsection{Bank capitalization}

It is expected that any time that banks are well capitalized, these banks then become very capable to offer loans and at lower lending rates(Borio \& Gambacorta, 2017; Brei, Gambacorta, \& von Peter, 2013). These banks are also generally considered more stable(Apergis \& Christou, 2015). Thus, well-capitalized banks are important to the advancement of the financial system (Zhuang et al., 2009). This study captures capitalizations as of the ratio of equity to total asset thus capturing capitalization in its ordinary sense.

3.3.8 Monetary Policy

One policy that can be said to boast of a direct impact on the financial system is monetary policy (Chadha \& Waters, 2014). It is an attempt by the central bank (or a similar body) to control the supply of money in an economy(Hassan \& Shahzad, 2011). One reason why this policy has been considered important in determining financial development is that it has a direct relationship with interest rates in most countries(Altunbas, Gambacorta, \& Marques-Ibanez, 2012; Gambacorta, 2009). Thus, higher monetary policy is characteristic of countries with high lending rates and less developed financial systems(Gambacorta, 2009). This policy is often set in different forms including inflation targeting, reserve ratio, policy rate and open market operations(Batini \&Turnbull, 2002; Partachi \& Mija, 2015; Rasche $\&$ Williams, 2007). This study uses monetary policy rate because it is easy to obtain.

\subsubsection{Exchange Rates}

It is conceivable that exchange rates could tell something about the degree of financial development within an economy. It is known that through exchange rate parity and interest rate parity, countries with higher interest rates tend to have weaker currencies. This suggests that these countries may also have weaker financial systems (Bjørnland, 2009; Eijffinger \& Karataș, 2012). This study measures the exchange rate using the real exchange rate index.

\subsubsection{Bank Size}

Bank size has been included as an independent variable to capture the effect of bank size on the development of financial sectors. It is expected that through economies of scale, big banks will perform the financial intermediation role more effectively (Kuranchie-Pong et al., 2016; Were \& Wambua, 2014). Ceteris paribus, banks grow more prominent over time and accumulate experiences that newer banks do not have(Behr, Foos, \& Norden, 2017). Besides, big banks would be able to hire high-quality staff than small banks, and these factors are expected to improve their efficiency in financial intermediation, demonstrated by lower interest rates(Tokle, Fullerton, \& Walke, 2015). It is 
thus, anticipated that bank size would have a significant impact on the overall development of the financial sector. Bank size is measured in this study using the natural log of the total assets of each bank.

\subsubsection{Profitability}

Banks make profits mainly because through interest on loans(George et al., 2013). The more affordable loans are, the more likely it is that a bank will attract borrowers(Quaye, Abrokwah, Sarbah, \& Osei, 2014). Thus, having profitable banks is expected to be a feature of a developed financial sector. This study proxies profitability by ROAA, return on average assets. This measure is easy to obtain and to interpret (Dong, Firth, Hou, \& Yang, 2014; Iannotta, Nocera, \& Sironi, 2007). The ROAA is computed as the profit before tax divided by the average total assets for a given year. Where the average total asset is the opening balance plus the closing balance divided by two.

\subsubsection{Financial Openness}

The measure of financial openness used in this study is taken from the KAOPEN (Chinn-Ito) index by Chinn \& Ito (2008). It indicates the level of regulation in the financial system of a country. It also shows how receptive the financial system is to external capital inflow or how much of foreign capital a country can attract.

\subsubsection{Liquidity}

Bank liquidity refers to the amount of cash and near cash assets that a bank has at a given time(Fiordelisi, Galloppo, \& Ricci, 2014). When banks are not liquid, they will default on their obligation to depositors(Li, Hsu, \& Qin, 2014). This study measures liquidity using the ratio of Liquid Assets to total deposits (LIQ). That is the ratio of liquid assets to total deposits and short-term borrowing (expressed as a percentage). Higher ratios are preferred as it indicates a bank's ability to meet its short-term liabilities as they fall due or unforeseen demand for funds.

The results of the data per this study are derived using the following:

\subsubsection{Model Specification}

Financial Development ${ }_{j t}$

$$
\begin{aligned}
& =\alpha_{i j}+\beta_{i j} \text { Bank Competition }_{j t}+\emptyset_{j} \sum_{j}^{n} \text { Country - level Control Variables }_{j t} \\
& +\varphi_{i} \sum_{i}^{n} \text { Bank - level Control Variables } j+\gamma_{i}+\mu_{j}+\varepsilon_{i t}
\end{aligned}
$$

where $\mathrm{i}=$ Bank, $\mathrm{j}=$ country, $\mathrm{t}=$ year, $\gamma=$ firm fixed effects, $\mu$ =country fixed effect, $\varepsilon=$ =error term

\subsubsection{Estimation Technique}

The model is estimated using the Fixed Effects estimation technique. This technique is like pooled OLS applied to time-demeaned variables hence removing time-invariant effects of the independent variables on the dependent variables (Drukker, 2003; Oscar, 2010). The Fixed Effects estimation is selected to tackle any potential endogeneity problems that may be inherent in the data(Baum, Schaffer, \& Stillman, 2007; Roodman, 2009). It also treats the consequences of omitted variable bias and has better identification characteristics(Cameron \& Trivedi, 2009; Hegre, Oneal, \& Russett, 2010; Ivanovic, 2016). The fixed effect is regarded to be more realistic since it is likely that unobserved effects are correlated with bank characteristics.

\subsection{RESULTS AND DISCUSSIONS}

\subsection{Data and Information Description}

This chapter presents an analysis of the data on bank competition and financial development in sub-Saharan Africa. The objective of such an analysis is to establish a relationship between the two phenomena. The analysis proceeds in two steps: first, the data is analysed for all sub-Saharan Africa countries included in the study. Secondly, the data is disaggregated into francophone and Anglophone countries, and these are investigated separated and compared. The section begins with a description of the characteristics of the data, first for the full sample and the data disaggregated into francophone and Anglophone countries. A correlation analysis follows to show the direction of the association between variables and the strength of the association. Finally, regression analysis is conducted to determine the marginal effects of the regressors on the financial development for the full sample of countries and then for the disaggregated sample.

\subsection{Descriptive Statistics}

This section presents a description of the characteristics of the variables that were employed in this study. These variables were grouped into bank-level variables and macro-level variables. The bank level variables include ROAA, 
SIZE, CAP, LIQ and NPLR. The macro-level variables include EXCH and MPR. CR3 represents banking sector competition.

4.2.1 Descriptive Statistics for Full Sample

The descriptive statistics for the full sample are shown in table 4.1. From the table, it can be observed that the banking sector of the countries included in the sample is weakly competitive. This can be seen from the mean of CR3 which 71. This means that there is little competition in the banking sector of these countries. Banking sector competition was measured using the concentration ratio of the three largest banks measured using the assets of these banks. The average figure shows that only three banks control $71 \%$ of the industry in most of the sampled countries over the study period. Comparing the mean, standard deviation and the minimum and maximum values for CR3, there is significant diversity among the countries tested in terms of the competition in their respective banking industries. With a standard deviation of 19\% from the analysis, it can be argued that the banking sectors of the sampled countries are not competitive.

The country with the most competitive banking sector as measured by the concentration ratio was Nigeria (observed from the metadata) because they recorded the lowest concentration ratios throughout the study. Looking at the trend for most countries, Nigeria's CR3 for each year has remained lower than most of the countries, suggesting that, that country has had a relatively more competitive banking sector. It can also be seen from table 4.1 that banks differ in term of their sizes. This is expected given the different capital requirements for banks across countries and the relative differences in the size of their economies. 
Table 4. 1 Descriptive Statistics for all countries bordering

\begin{tabular}{|c|c|c|c|c|c|}
\hline Variable & Obs. & Mean & Std. Dev. & Min & Max \\
\hline CR3 & 7104 & 71.35 & 18.90007 & 23.32425 & 100 \\
\hline SIZE & 4838 & 12.28 & 1.77549 & 3.130835 & 19.02797 \\
\hline FINOPP & 8334 & -.36 & 1.432901 & -1.894798 & 2.389193 \\
\hline $\mathrm{EXCH}$ & 4366 & 103.18 & 51.93805 & 54.10885 & 827.1707 \\
\hline MPR & 7325 & 10.62 & 7.314182 & 1.395537 & 70 \\
\hline FDCredit & 8664 & 21.69272 & 20.13998 & .410356 & 106.26 \\
\hline $\mathrm{BM}$ & 8664 & 33.75523 & 21.7725 & 2.85741 & 150.685 \\
\hline ROAA & 4734 & 1.445484 & 6.442268 & -168.424 & 139.72 \\
\hline CAP & 4780 & 16.93124 & 17.3907 & -83.729 & 99.855 \\
\hline ZSCORE & 4780 & 12.72399 & 16.36416 & -96.1954 & 313.2705 \\
\hline LIQ & 3965 & 46.941 & 21.07908 & .006 & 100 \\
\hline NPLR & 2183 & 9.192601 & 11.57289 & .014 & 105.413 \\
\hline
\end{tabular}

From the table, the mean value of financial openness was -0.36 which shows that countries are less open financially. Also, the mean of the exchange rate index shows that currencies of the countries in the sample depreciated by $3.18 \%$ on average over the period. There is however a wide dispersion in the distribution of the variable; which is expected given the diversity of the economies of the countries. The wide dispersion is also attributable to the fact that some francophone countries have pegged their currency to the Euro and so the currency does not adjust to reflect the more volatile local economy. The monetary policy rate was about $10 \%$ on average over the period. This however varied significantly across countries- a reflection of the diverse nature of the financial economy of Africa. The table also shows that on average financial institutions give credit up to $21 \%$ of GDP each year and the broad money is $33 \%$ on average.

On the banking sector-specific variables, it can be seen from table 4.1 that banks' return on average assets was about $1.4 \%$ per annum. The ZSCORE was also about $12 \%$ on average whiles capitalization was $46 \%$ and nonperforming loans ratio was $9 \%$. It can be argued that except for ROAA, the banking sector variables show that the sector is doing well. It is however necessary to disaggregate these values to be able to take into consideration the differences in the characteristics of the countries. This is considered to be significant given that the statistics in table 4.1 show that there are wide variations in the distribution of the data.

4.2.2 Summary statistics for Anglophone countries

Table 4.2 below shows summary statistics of Anglophone countries in the sample. The table shows that banks in Anglophone countries are more competitive than the full sample and francophone countries. This is demonstrated by the mean of CR3 in table 4.2 which is $67 \%$ compared to $71 \%$ in the entire sample. The table also shows that banks in Anglophone countries tend to be bigger than the typical bank in sub-Saharan Africa.

Table 4.2 also reveals that Anglophone countries are more financial open than the rest of sub-Saharan Africa. This is evident by the mean of FINOP in table 4.2 compared to -.36 in table 4.1. The table also shows that Anglophone countries have stronger currencies on average than the typical currencies as can be seen from the mean of EXCH in table 4.2. Also, there is less variation in the strength of their currencies relative to each other compared to table 4.1. The average monetary policy rate of these countries was however higher than in table 4.1 showing that on average, their interest rates were higher than for the rest of the sample. 
Table 4. 2 Descriptive Statistics for Anglophone countries

\begin{tabular}{llllll}
\hline Variable & Obs. & Mean & Std. Dev. & Min & Max \\
CR3 & 3993 & 66.65612 & 19.67072 & 23.32425 & 100 \\
SIZE & 2626 & 12.31248 & 1.955016 & 4.392698 & 19.02797 \\
FINOP & 4504 & .0370736 & 1.570042 & -1.894798 & 2.389193 \\
EXCH & 2866 & 96.25546 & 15.95761 & 54.10885 & 160.2254 \\
MPR & 4170 & 13.28086 & 6.350337 & 2.765 & 46.8 \\
FDCredit & 4808 & 22.50448 & 19.30509 & 1.52245 & 78.2941 \\
BM & 4808 & 33.48525 & 18.91023 & 8.89452 & 150.685 \\
ROAA & 2553 & 1.902781 & 7.337696 & -168.424 & 139.72 \\
CAP & 2580 & 19.34267 & 18.84566 & -83.729 & 99.855 \\
ZSCORE & 2580 & 12.72778 & 15.52188 & -96.1954 & 243.1968 \\
LIQ & 2152 & 45.89565 & 19.21922 & .006 & 97.305 \\
NPLR & 1245 & 8.712979 & 11.14819 & .018 & 100 \\
\hline \multicolumn{7}{l}{ This table shows anglophone sample descriptive statistics for Bank Competition (CR3) and Financial } \\
Development (BM and FDCredit); country-level control variables: Financial Openness (FINOPP), Exchange \\
Rate (EXCH), Monetary Policy (MPR); and bank level controls: Bank Size (SIZE), Profitability (ROAA), Bank \\
\multicolumn{5}{l}{ Capitalization (CAP), Bank Stability (ZSCORE), Bank Liquidity (LIQ) and Non-Performing Loans (NPLR) } \\
\hline
\end{tabular}

Table 4.2 also shows that on the bank-level variables, Anglophone countries performed better on all variables than in the full sample as shown in table 4.1 except liquidity and ZSCORE. This includes a lower mean NPL ratio of $8.7 \%$ compared to $9 \%$ in table 4.1 and mean of ROAA of $1.9 \%$ compared to $1.4 \%$ in table 4.1 . On liquidity, Anglophone banks performed marginally lower than the rest of sub-Saharan Africa with a ratio of $45.89 \%$ compared to $46.91 \%$ in table 4.1 . They were also less stable as shown by the ZSCORE in table 4.2 which is lower than in table 4.1

4.2.3 Summary statistics for Francophone countries

Table 4.3 shows descriptive statistics for francophone countries. The table shows that francophone countries have less competitive banking sectors than the rest of sub-Saharan Africa and Anglophone countries. This can be seen from the mean of CR3 in table 4.3 of $74.8 \%$ compared to $71 \%$ in table 4.1 and $67 \%$ in table 4.2 . Banks in francophone countries also tend to be smaller than for the typical bank in sub-Saharan Africa and for Anglophone banks, as can be seen from the mean of size in table 4.3 compared to those in table 4.1 and table 4.2 .

Table 4. 3 Descriptive Statistics for francophone countries

\begin{tabular}{llllll}
\hline Variable & Obs. & Mean & Std. Dev. & Min & Max \\
CR3 & 2330 & 74.81293 & 16.41059 & 46.08878 & 100 \\
SIZE & 1702 & 12.10433 & 1.399583 & 3.130835 & 15.78497 \\
FINOP & 2909 & -.7017703 & 1.173624 & -1.894798 & 2.389193 \\
EXCH & 1500 & 116.4228 & 84.26906 & 59.16139 & 827.1707 \\
MPR & 2638 & 6.512886 & 7.421947 & 1.395537 & 70 \\
FDCredit & 2995 & 20.49104 & 22.62808 & .410356 & 106.26 \\
BM & 2995 & 32.47634 & 26.05013 & 2.85741 & 110.769 \\
ROAA & 1659 & .9129096 & 4.747681 & -50 & 78.367 \\
CAP & 1674 & 13.91759 & 15.76034 & -45.44 & 99.827
\end{tabular}




\begin{tabular}{llllll} 
ZSCORE & 1674 & 13.3907 & 19.21075 & -18.1917 & 313.2705 \\
LIQ & 1295 & 48.43481 & 23.57794 & .009 & 100 \\
NPLR & 692 & 10.47634 & 12.30807 & .014 & 105.413 \\
\hline This table shows & francophone sample descriptive & statistics for & Bank & Competition (CR3) and Financial \\
Development (BM and FDCredit); country-level control variables: Financial Openness (FINOPP), Exchange \\
Rate (EXCH), Monetary Policy (MPR); and bank level controls: Bank Size (SIZE), Profitability (ROAA), Bank \\
Capitalization (CAP), Bank Stability (ZSCORE), Bank Liquidity (LIQ) and Non-Performing Loans (NPLR) \\
\hline
\end{tabular}

The table also shows that the financial sector of francophone tends to be less open than the rest of sub-Saharan Africa and Anglophone countries. This is demonstrated by the coefficient of FINOPP of -0.7 in table 4.3 compared to -.36 in table 4.1 and 0.04 in table 4.2. This could be explained by the fact that the financial sector of francophone countries is based on a colonial structure that is dependent on France. Similarly, they tend to have weaker currencies as shown by the mean of EXCH of $116 \%$ compared to lower values in table 4.1 and table 4.2. The table also shows that the financial sector of Francophone countries gives credit of about $20 \%$ of GDP per annum on average compared to $22 \%$ for Anglophone countries, and their broad money to GDP ratio stood at $32 \%$ compared to $33 \%$ for Anglophone countries.

On the bank level variables, it can be seen from the table that banks in francophone countries were significantly more liquid than and more stable than their Anglophone counterparts (table 4.2). They, however, had high nonperforming loans and significantly less capitalized than their Anglophone counterparts (table 4.3).

\subsection{Correlation Analysis and Discussion}

This section presents the results of the correlation analysis to show the degree of association between pairs of variables. The first part gives the results for the full sample of countries while the second and third parts present results for the Anglophone and Francophone disaggregated samples respectively.

\subsubsection{Correlation results for the full sample}

Table 4.4 shows correlation results for the full sample of countries included in this study. From the table, it can be seen that financial development (FDCredit) has a negative correlation with competition (CR3). This means that when banking sector competition is low financial firms advance less credit relative to when there is higher competition. This makes sense because weak competition means that fewer banks have control of the market. To begin with, there may be fewer banks in all and this means that their capacity to lend to a large base of borrowers is reduced, hence it makes sense to observe that less competitive industries would advance less credit.

The correlation between FDCredit and size is positive and shows that countries with bigger banks tend to have higher credit advanced to their private sector. This also makes sense given that the size of the banks is an indicator of their lending capacity. Bigger banks tend to attract higher investments and mobilize more deposits and so are better placed to advance credit. FDCredit has a negative correlation with EXCH; this means that countries with weaker exchange rates have less developed financial markets.

This is intuitive given that the stability or otherwise of the domestic currency is a reflection of the strength of the local financial markets. It can also be said that because the currencies of the countries have depreciated over time (see table 4.1), the value of the loans in dollar terms (USD values were used for this study) will be lower, ceteris paribus, even if the local currency amount has increased.

FDCredit has a positive relationship with FINOP which is expected. It is plausible because a financially open country attracts foreign investments and so there will be a more significant supply of loanable funds compared to a less open country. MPR and FDCredit show a negative relationship. Monetary policy rates are indicators of the level of inflation and the prevailing interest rates. High-interest rates will discourage borrowing, and so it makes sense to observe that when MPR is high, less credit is used in the economy. ROAA, CAP and ZSCORE have positive correlations with FDCredit. This means that banks are more profitable, better capitalized and stable in financially developed countries. These banks also tend to advance more credit to the private sector. It is not difficult to see that this makes sense since these are characteristics of developed financial markets. 
Liquidity and NPLR, however, have negative correlations but these are not significant given the size of their coefficients. The other measure of financial development is the ratio of broad money to GDP (BM). The relationships between BM and all other variables are similar to FDCredit except CR3. This means that countries with weak banking sector competitions will have higher money demand. This is expected since fewer banks indicate that there will be fewer savings channels and so people will tend to hold cash. Overall, there is no reason to suspect multicollinearity, and so regression analysis using the data would generate unbiased parameter estimates, ceteris paribus. 
Table 4.4 correlation matrix for all countries

\begin{tabular}{|c|c|c|c|c|c|c|c|c|c|c|c|c|}
\hline & CR3 & SIZE & FINOPP & $\mathrm{EXCH}$ & MPR & ROAA & CAP & ZSCORE & LIQ & NPLR & $\mathrm{BM}$ & FDCredit \\
\hline CR3 & 1 & & & & & & & & & & & \\
\hline SIZE & -0.06 & 1 & & & & & & & & & & \\
\hline FINOP & -0.30 & -0.05 & 1 & & & & & & & & & \\
\hline $\mathrm{EXCH}$ & 0.02 & -0.07 & -0.04 & 1 & & & & & & & & \\
\hline MPR & -0.06 & -0.14 & 0.18 & 0.42 & 1 & & & & & & & \\
\hline ROAA & 0.05 & 0.13 & 0.00 & -0.07 & 0.00 & 1 & & & & & & \\
\hline CAP & 0.01 & -0.12 & 0.08 & 0.03 & 0.08 & 0.14 & 1 & & & & & \\
\hline ZSCORE & -0.02 & -0.03 & 0.03 & -0.01 & -0.03 & 0.08 & 0.37 & 1 & & & & \\
\hline LIQ & 0.016 & 0.01 & -0.04 & -0.02 & -0.02 & -0.04 & -0.03 & 0.03 & 1 & & & \\
\hline NPLR & 0.02 & 0.00 & -0.08 & 0.00 & -0.04 & 0.01 & 0.04 & 0.03 & -0.12 & 1 & & \\
\hline BM & 0.02 & 0.30 & 0.17 & -0.21 & -0.20 & 0.06 & 0.12 & 0.07 & -0.02 & -0.03 & 1 & \\
\hline FDCredit & -0.04 & 0.34 & 0.12 & -0.17 & -0.22 & 0.08 & 0.15 & 0.07 & -0.00 & -0.01 & 0.87 & 1 \\
\hline
\end{tabular}




\subsubsection{Correlation results for Anglophone sample}

Table 4.5 shows the results of the correlation analysis for the Anglophone sample. From the table, it can be seen that financial development (FDCredit) has a positive correlation with competition compared to a negative correlation in the full sample (table 4.4). This means that unlike the typical country in the full sample, for Anglophone countries when banking sector competition is high financial firms advance more credit. This makes sense because high competition means that many banks are all trying to serve customers in the market. Thus there will be a higher supply of credit on average. The correlation between FDCredit and size is positive and shows that Anglophone countries with bigger banks tend to have higher credit advanced to their private sector.

This is expected given that the size of the banks is an indicator of their lending capacity. Bigger banks tend to attract higher investments and mobilize more deposits and so are better placed to advance credit. FDCredit has a negative correlation with $\mathrm{EXCH}$; this means that francophone countries with weaker exchange rates have less developed financial markets. This is also expected given that the stability or otherwise of the domestic currency is a reflection of the strength of the local financial markets.

FDCredit has a negative relationship with FINOP compared to a positive relationship in table 4.4 which is unexpected. It is difficult to explain this relationship because a financially open country attracts foreign investments and so there will be a more significant supply of loanable funds compared to a less open country. It is therefore surprising that for Anglophone countries, less open ones have a higher supply of credit. One possible explanation is that these countries mobilize enough domestic funds and they rely less on foreign credit. MPR and FDCredit show a negative relationship as it did in table 4.1. A similar explanation could, therefore, be used. That is, monetary policy rates are indicators of the level of inflation and the prevailing interest rates. High-interest rates will discourage borrowing, and so it makes sense to observe that when MPR is high, less credit is used in the economy. ROAA, CAP and ZSCORE have positive correlations with FDCredit just as in table 4.4. This means that banks are more profitable, better capitalized and stable in financially developed countries. These banks also tend to advance more credit to the private sector. It is not difficult to see that this makes sense since these are characteristics of developed financial markets.

Contrary to results in table 4.4 however, liquidity and NPLR, however, have positive correlations with FDCredit for Anglophone countries. It shows that for Anglophone countries with better developed financial markets, banks tend to have better liquidity and higher non-performing loans than in table 4.1. The other measure of financial development is the ratio of broad money to GDP (BM). The relationships between BM and all other variables are similar to FDCredit. FDCredit and BM also have a strong correlation as expected. Overall, there is no reason to suspect multicollinearity, and so regression analysis using the data would generate unbiased parameter estimates, ceteris paribus. 
Table 4. 5 correlation matrix for Anglophone countries

\begin{tabular}{|c|c|c|c|c|c|c|c|c|c|c|c|c|}
\hline & CR3 & SIZE & FINOP & $\mathrm{EXCH}$ & MPR & ROAA & CAP & ZSCORE & LIQ & NPLR & FDCredit & $\mathrm{BM}$ \\
\hline CR3 & 1 & & & & & & & & & & & \\
\hline SIZE & 0.04 & 1 & & & & & & & & & & \\
\hline FINOP & -0.24 & -0.14 & 1 & & & & & & & & & \\
\hline $\mathrm{EXCH}$ & 0.12 & -0.08 & 0.10 & 1 & & & & & & & & \\
\hline MPR & 0.07 & -0.22 & 0.07 & -0.01 & 1 & & & & & & & \\
\hline ROAA & 0.09 & 0.13 & -0.05 & -0.06 & -0.03 & 1 & & & & & & \\
\hline CAP & 0.06 & -0.08 & -0.01 & 0.03 & -0.07 & 0.22 & 1 & & & & & \\
\hline ZSCORE & -0.04 & -0.03 & -0.00 & 0.05 & -0.07 & 0.06 & 0.40 & 1 & & & & \\
\hline LIQ & 0.05 & -0.03 & -0.01 & -0.06 & 0.04 & -0.03 & -0.03 & -0.00 & 100 & & & \\
\hline NPLR & -0.01 & 0.08 & -0.06 & 0.01 & 0.00 & 0.04 & 0.01 & -0.01 & -0.08 & 1 & & \\
\hline FDCredit & 0.18 & 0.40 & -0.21 & -0.30 & -0.43 & 0.13 & 0.19 & 0.06 & 0.0 & 0.05 & 1 & \\
\hline $\mathrm{BM}$ & 0.22 & 0.36 & -0.15 & -0.34 & -0.37 & 0.11 & 0.16 & 0.06 & 0.01 & 0.00 & 0.84 & 1 \\
\hline
\end{tabular}

This matrix shows correlations for the anglophone sample for Bank Competition (CR3) and Financial Development (BM and FDCredit); country-level control variables: Financial Openness (FINOPP), Exchange Rate (EXCH), Monetary Policy (MPR); and bank level controls: Bank Size (SIZE), Profitability (ROAA), Bank Capitalization (CAP), Bank Stability (ZSCORE), Bank Liquidity (LIQ) and Non-Performing Loans (NPLR) 


\subsubsection{Correlation results for francophone sample}

Table 4.6 shows correlation results for the francophone sample. The table shows that correlation between financial development (FDCredit) and competition (CR3) is negative as in the full sample. This means that when banking sector competition is low financial firms advance less credit relative to when there is higher competition as in table 4.1. This makes sense because weak competition means that fewer banks have control of the market. The data also shows that francophone countries have less competitive banking sectors on average than the full sample and Anglophone sample. It suggests therefore that francophone countries have lower financial development compared to Anglophone countries.

The correlation between FDCredit and size is positive for francophone countries as in the full sample (table 4.4) and the francophone sample (table4.5). This shows that countries with bigger banks tend to have higher credit advanced to their private sector regardless of whether they are Anglophone or francophone. Generally, this is intuitive because the size of banks is usually taken as an indicator of the amount of lending they can do. FDCredit has a negative correlation with EXCH for francophone countries as in the full sample. This means that francophone countries with weaker exchange rates have less developed financial markets. It is important to observe that francophone countries in Africa share common currencies in blocs. This means that the blocs whose currencies are weaker also have a less developed financial market.

FDCredit has a positive relationship with FINOP as in the full sample which is expected. Thus, financially open francophone countries attract foreign investments and so there will be a more significant supply of loanable funds in those countries compared to a less open country. MPR and FDCredit show a negative relationship as in the full sample (table 4.4). As explained in the previous case, monetary policy rates are indicators of the level of inflation and the prevailing interest rates. Thus high-interest rates will discourage borrowing, and so it makes sense to observe that when MPR is high, less credit is used in the economy. It is also important to note that interest rates (MPR) are lower in francophone countries (table 4.3) than in Anglophone countries (table 4.2). This means that this effect will be smaller for francophone countries. ROAA, CAP and ZSCORE have positive correlations with FDCredit. This means that banks are more profitable, better capitalized and stable in financially developed francophone countries.

Liquidity and NPLR, however, have negative correlations with FDCredit as in the full sample but these have larger coefficients than the full sample. The other measure of financial development is the ratio of broad money to GDP $(\mathrm{BM})$. The relationships between BM and all other variables are similar to FDCredit. Also, the correlation between the two measures of financial development is most active in the francophone sample with a coefficient of 0.91 . Overall, there is no reason to suspect multicollinearity, and so regression analysis using the data would generate unbiased parameter estimates, ceteris paribus 
Table 4.6correlation matrix for Francophone countries

\begin{tabular}{|c|c|c|c|c|c|c|c|c|c|c|c|c|}
\hline & CR3 & SIZE & FINOP & $\mathrm{EXCH}$ & MPR & ROAA & CAP & ZSCORE & LIQ & NPLR & FDCredit & $\mathrm{BM}$ \\
\hline CR3 & 1 & & & & & & & & & & & \\
\hline SIZE & -0.31 & 1 & & & & & & & & & & \\
\hline FINOP & -0.21 & 0.28 & 1 & & & & & & & & & \\
\hline $\mathrm{EXCH}$ & -0.06 & -0.08 & 0.11 & 1 & & & & & & & & \\
\hline MPR & -0.08 & -0.17 & -0.02 & 0.77 & 1 & & & & & & & \\
\hline ROAA & 0.05 & 0.11 & 0.04 & -0.09 & -0.05 & 1 & & & & & & \\
\hline CAP & 0.02 & -0.12 & 0.14 & 0.11 & 0.14 & 0.03 & 1 & & & & & \\
\hline ZSCORE & 0.02 & -0.03 & 0.06 & -0.01 & 0.01 & 0.08 & 0.36 & 1 & & & & \\
\hline LIQ & -0.09 & 0.09 & -0.09 & -0.01 & -0.02 & 0.04 & -0.07 & 0.09 & 1 & & & \\
\hline NPLR & 0.02 & -0.09 & -0.14 & -0.02 & 0.01 & -0.06 & 0.11 & 0.07 & -0.13 & 1 & & \\
\hline FDCredit & -0.37 & 0.37 & 0.77 & -0.25 & -0.09 & 0.02 & 0.14 & 0.08 & -0.01 & -0.11 & 1 & \\
\hline $\mathrm{BM}$ & -0.28 & 0.33 & 0.83 & -0.27 & -0.14 & 0.03 & 0.15 & 0.077 & -0.04 & -0.09 & 0.91 & 1 \\
\hline
\end{tabular}

This matrix shows correlations for the francophone sample for Bank Competition (CR3) and Financial Development (BM and FDCredit); country-level control variables: Financial Openness (FINOPP), Exchange Rate (EXCH), Monetary Policy (MPR); and bank level controls: Bank Size (SIZE), Profitability (ROAA), Bank Capitalization (CAP), Bank Stability (ZSCORE), Bank Liquidity (LIQ) and Non-Performing Loans (NPLR) 


\subsection{Regression Analysis and Discussion}

This section presents the regression results for sub-Saharan Africa and the disaggregated samples of Anglophone and Francophone countries.

\subsubsection{Full sample regression results}

Table 4.7 shows the regression results for all the countries in the sample with BM as the dependent variable. The results show that BM and CR3 are positively related confirming the correlation results. This relationship is however not statistically significant. In this table, the only statistically significant variable is the size. Size has a positive relationship with $\mathrm{BM}$ with a coefficient of 2.36. This means that an increase in the size of 1 percentage point leads to an increase in the BM by 2.36 percentage points. This is very significant economically given the mean of size in table 4.1. It can thus be concluded that having bigger banks is associated with higher financial development.

Table 4. 7 Full Sample Regression-BM

\begin{tabular}{|c|c|c|c|c|c|c|}
\hline \multicolumn{4}{|c|}{ Fixed-effects (within) regression } & \multicolumn{3}{|c|}{ Number of obs. $=389$} \\
\hline \multicolumn{4}{|c|}{ Group variable: PANELID } & \multicolumn{3}{|c|}{ Number of groups $=139$} \\
\hline \multicolumn{4}{|c|}{$\begin{array}{l}\text { R-sq.: within }=0.1298 \\
\text { between }=0.1694 \\
\text { overall }=0.1897\end{array}$} & \multicolumn{3}{|c|}{$\begin{array}{l}\text { Obs. per group: } \min =1 \\
\text { Avg. }=2.8 \\
\text { Max. }=14\end{array}$} \\
\hline \multicolumn{4}{|c|}{ Corr. (u_i, Xb) $=0.2138$} & \multicolumn{2}{|c|}{$\mathrm{F}(10,240)=3.58$} & Prob. $>\mathrm{F}=0.0002$ \\
\hline $\mathrm{BM}$ & Coef. & Std. Err. & $\mathrm{T}$ & $\mathrm{P}>\mathrm{t}$ & \multicolumn{2}{|c|}{ [95\% Conf. Interval] } \\
\hline CR3 & .0341594 & .0396092 & 0.86 & 0.389 & -.0438666 & .1121855 \\
\hline SIZE & 2.359312 & .46981 & 5.02 & 0.000 & 1.433834 & 3.284789 \\
\hline FINOP & .2940213 & 1.84627 & 0.16 & 0.874 & -3.342941 & 3.930983 \\
\hline $\mathrm{EXCH}$ & -.0076266 & .0089985 & -0.85 & 0.398 & -.0253527 & .0100995 \\
\hline MPR & .0139983 & .0739236 & 0.19 & 0.850 & -.1316237 & .1596203 \\
\hline ROAA & .151127 & .1242604 & 1.22 & 0.225 & -.0936532 & .3959072 \\
\hline CAP & .061128 & .0428854 & 1.43 & 0.155 & -.0233519 & .1456079 \\
\hline ZSCORE & .0820653 & .0829715 & 0.99 & 0.324 & -.08138 & .2455106 \\
\hline LIQ & -.0025111 & .0336184 & -0.07 & 0.941 & -.0687358 & .0637136 \\
\hline NPLR & -.0491039 & .0360552 & -1.36 & 0.175 & -.120129 & .0219211 \\
\hline _cons & -1.400144 & 7.592779 & -0.18 & 0.854 & -16.35714 & 13.55685 \\
\hline F-test tha & $\mathrm{i}=0: \quad \mathrm{F}(13$ & $240)=25.79$ & & $=0.0$ & & \\
\hline
\end{tabular}

Table 4.8 presents the full-sample regression results for FDCredit. The results in table d.8 show that CR3 has a coefficient of 0.064 and this is statistically significant. This means that when the level of competition reduces by 1 percentage point, the amount of credit that is offered increases by 0.064 percentage point. This suggests that overall, having less competition in the banking sector is good for financial development in sub-Saharan Africa. This is contrary to expectation and will be discussed further later. Size also shows a significant positive relationship with financial development. The results suggest that when bank size increases by 1 percentage point, financial development increases by 1.5 percentage points. Thus financial development is elastic to bank size; this is similar to the outcome when BM was used as a proxy for financial development in table 4.7 and shows the impact of size on financial development is robust to the choice of proxy.

Table 4. 8 Full Sample Regression-FDCredit

\begin{tabular}{|l|l|}
\hline Fixed-effects (within) regression & Number of obs. $=389$ \\
\hline Group variable: PANELID & Number of groups $=139$ \\
\hline R-sq.: within $=0.1077$ & Obs. per group: $\min =1$ \\
between $=0.2681$ & Avg. $=2.8$ \\
overall $=0.2386$ & Max. $=14$ \\
\hline Corr. $\left(\mathrm{u} \_\mathrm{i}, \mathrm{Xb}\right)=0.2824$ & $\mathrm{~F}(10,240)=2.90$ Prob. $>\mathrm{F}=0.0019$ \\
\hline
\end{tabular}




\begin{tabular}{|l|l|l|l|l|l|l|}
\hline FDCredit & Coef. & Std. Err. & T & P $>\mathrm{t}$ & \multicolumn{2}{l|}{$[95 \%$ Conf. Interval] } \\
\hline CR3 & .0641292 & .0341231 & 1.88 & 0.061 & -.0030899 & .1313482 \\
\hline SIZE & 1.547272 & .4047388 & 3.82 & 0.000 & .7499778 & 2.344566 \\
\hline FINOP & -1.497088 & 1.590551 & -0.94 & 0.348 & -4.630311 & 1.636135 \\
\hline EXCH & -.0030252 & .0077521 & -0.39 & 0.697 & -.0182961 & .0122457 \\
\hline MPR & -.0156957 & .0636848 & -0.25 & 0.806 & -.1411483 & .1097569 \\
\hline ROAA & .1918987 & .1070496 & 1.79 & 0.074 & -.0189781 & .4027755 \\
\hline CAP & .0312593 & .0369456 & 0.85 & 0.398 & -.0415196 & .1040383 \\
\hline ZSCORE & -.0087532 & .0714795 & -0.12 & 0.903 & -.1495604 & .1320541 \\
\hline LIQ & .0306911 & .028962 & 1.06 & 0.290 & -.0263611 & .0877434 \\
\hline NPLR & .0133802 & .0310614 & 0.43 & 0.667 & -.0478075 & .0745679 \\
\hline _cons & -5.49873 & 6.541138 & -0.84 & 0.401 & -18.3841 & 7.386642 \\
\hline F test that all u_i $=0: \mathrm{F}(138,240)=39.24$ & Prob.> F =0.0000 & & \\
\hline
\end{tabular}

ROAA shows a significant positive relationship with financial development. The results show that a one percentage point increase in the profitability of banks results in an increase of 0.19 percentage point in financial development. Contrary to expectations, however, other macroeconomic factors did not show significant relationships with financial development.

4.4.2 Anglophone sample regression results

The results for the Anglophone regression is presented in table 4.9 and table 4.10. Table 4.9 shows the results for $\mathrm{BM}$ as a proxy for financial development. The results show that in anglophone countries, there is no significant relationship between bank competition and BM. However, the size of banks shows a significant relationship with $\mathrm{BM}$ and a one percentage point increase in the size of banks on average will increase BM by 1.6 percentage points. Other variables such as EXCH showed a negative and significant relationship with BM. It shows that a one percentage point increase in the depreciation of average exchange rates in Anglophone countries reduces BM and weakens financial development. Thus currency depreciation is terrible for financial development. ZSCORE has a positive and significant relationship with $\mathrm{BM}$, and this is interpreted to mean that an increase in the stability of banks leads to an increase in BM or improvement in financial development. 
Table 4. 9 Anglophone Regression-BM

\begin{tabular}{|c|c|c|c|c|c|c|}
\hline \multicolumn{4}{|c|}{ Fixed-effects (within) regression } & \multicolumn{3}{|c|}{ Number of obs. $=267$} \\
\hline \multicolumn{4}{|c|}{ Group variable: PANELID } & \multicolumn{3}{|c|}{ Number of groups $=98$} \\
\hline \multicolumn{4}{|c|}{$\begin{array}{l}\text { R-sq.: within }=0.2191 \\
\text { between }=0.2873 \\
\text { overall }=0.2714\end{array}$} & \multicolumn{3}{|c|}{$\begin{array}{l}\text { Obs. per group: } \min =1 \\
\text { Avg. }=2.7 \\
\text { Max. }=14\end{array}$} \\
\hline \multicolumn{4}{|c|}{ Corr.(u_i, Xb) $=0.3553$} & $\mathrm{~F}(10,159)=4.46$ & \multicolumn{2}{|c|}{ Prob. $>\mathrm{F}=0.0000$} \\
\hline $\mathrm{BM}$ & Coef. & Std. Err. & $\mathrm{T}$ & $\mathrm{P}>\mathrm{t}$ & \multicolumn{2}{|c|}{ [95\% Conf. Interval] } \\
\hline CR3 & .0532993 & .0412828 & 1.29 & 0.199 & -.028234 & .1348326 \\
\hline SIZE & 1.649562 & .468379 & 3.52 & 0.001 & .7245154 & 2.574609 \\
\hline FINOP & .4742492 & 1.797449 & 0.26 & 0.792 & -3.075705 & 4.024204 \\
\hline EXCH & -.111883 & .0241515 & -4.63 & 0.000 & -.1595821 & -.0641839 \\
\hline MPR & -.00081 & .0697619 & -0.01 & 0.991 & -.1385896 & .1369696 \\
\hline ROAA & .0921942 & .125151 & 0.74 & 0.462 & -.1549785 & .339367 \\
\hline CAP & .0383486 & .0409805 & 0.94 & 0.351 & -.0425878 & .1192849 \\
\hline ZSCORE & .2094198 & .0844679 & 2.48 & 0.014 & .042596 & .3762437 \\
\hline LIQ & .0001568 & .0367875 & 0.00 & 0.997 & -.0724983 & .0728119 \\
\hline NPLR & -.0096172 & .0370347 & -0.26 & 0.795 & -.0827607 & .0635263 \\
\hline _cons & 16.78084 & 8.014748 & 2.09 & 0.038 & .9517459 & 32.60994 \\
\hline \multicolumn{7}{|c|}{$F$ test that all $u_{i} \mathrm{i}=0$ : } \\
\hline
\end{tabular}

Table 4.10 shows the results for FDCredit for Anglophone countries. Similar to the full sample estimates, the relationship between competition and financial development is positive and significant. The results show that an increase in competition by one percentage point will improve financial development by $0.09 \%$. It can be observed that the marginal effect of competition on FDCredit is higher for Anglophone countries than the full sample. It is concluded therefore that competition has a higher benefit for financial development in Anglophone countries compared to the full sample of countries. 
Table 4. 10 Anglophone Regression-FDCredit

\begin{tabular}{|c|c|c|c|c|c|c|}
\hline \multicolumn{4}{|c|}{ Fixed-effects (within) regression } & \multicolumn{3}{|c|}{ Number of obs. $=267$} \\
\hline \multicolumn{4}{|c|}{ Group variable: PANELID } & \multicolumn{3}{|c|}{ Number of groups $=98$} \\
\hline \multicolumn{4}{|c|}{$\begin{array}{l}\text { R-sq.: within }=0.1628 \\
\text { between }=0.3162 \\
\text { overall }=0.2493\end{array}$} & \multicolumn{3}{|c|}{$\begin{array}{l}\text { Obs. per group: } \min =1 \\
\text { Avg. }=2.7 \\
\text { Max. }=14\end{array}$} \\
\hline \multicolumn{4}{|c|}{$\operatorname{corr}\left(\mathrm{u} \_\mathrm{i}, \mathrm{Xb}\right)=0.2591$} & \multicolumn{3}{|c|}{$\mathrm{F}(10,159)=3.09$ Prob $>\mathrm{F}=0.0013$} \\
\hline FDCredit & Coef. & Std. Err. & $\mathrm{T}$ & $\mathrm{P}>\mathrm{t}$ & \multicolumn{2}{|c|}{ [95\% Conf. Interval] } \\
\hline CR3 & .0860261 & .0380979 & 2.26 & 0.025 & .0107829 & .1612694 \\
\hline SIZE & .9310464 & .4322447 & 2.15 & 0.033 & .0773646 & 1.784728 \\
\hline FINOP & -2.332146 & 1.65878 & -1.41 & 0.162 & -5.60823 & .9439384 \\
\hline EXCH & -.0635505 & .0222883 & -2.85 & 0.005 & -.1075697 & -.0195312 \\
\hline MPR & -.0183034 & .06438 & -0.28 & 0.777 & -.1454537 & .1088468 \\
\hline ROAA & .1599626 & .1154959 & 1.39 & 0.168 & -.0681415 & .3880666 \\
\hline CAP & .0093983 & .037819 & 0.25 & 0.804 & -.065294 & .0840906 \\
\hline ZSCORE & .0642475 & .0779514 & 0.82 & 0.411 & -.0897063 & .2182013 \\
\hline LIQ & .0280917 & .0339494 & 0.83 & 0.409 & -.0389582 & .0951416 \\
\hline NPLR & .0338893 & .0341776 & 0.99 & 0.323 & -.0336113 & .10139 \\
\hline _cons & 9.116996 & 7.39643 & 1.23 & 0.220 & -5.490925 & 23.72492 \\
\hline \multicolumn{7}{|c|}{ F test that all u_i=0: $\quad \mathrm{F}(97,159)=39.06$} \\
\hline
\end{tabular}

Bank size has a positive and significant relationship with FDCredit. This shows that big banks are beneficial to the financial development of Anglophone countries. The results show that a one percentage point increase in the average size of banks leads to an improvement in financial development by 0.93 percentage point. Compared to the full sample, it can be seen that size matters less for Anglophone countries than the full sample. In table 4.10, the only macroeconomic variable that has a significant relationship with FDCredit is EXCH. It shows that weak currency is bad for financial development and a unit increase in the index could reduce the amount of credit extended to the private sector in Anglophone countries by 0.064 percentage point.

\subsubsection{Francophone sample regression results}

Table 4.11 shows results of regression for BM for francophone countries and table 4.12 shows results for FDCredit for francophone countries. The results in table 4.11 show that competition does not affect BM in francophone countries., however, continues to show a positive effect on BM as in the full sample and the Anglophone sample. The estimate is interpreted to mean that a percentage point increase in the size of banks leads to an increase of 9.4 percentage points in the BM.

The marginal effect is higher than for the full sample and the Anglophone sample suggesting that bank size is more important for the financial development of francophone countries than for Anglophone countries. ROAA is marginally significant for the francophone sample. It can be seen a percentage point increase in the ROAA of banks results in an increase in BM of 0.43 percentage points. Similarly, CAP has a marginal effect of 0.39 percentage point for every one percentage point increase on the BM. This result shows that better-capitalized banks and banks that have higher ROAA lead to the higher money supply in francophone countries.

ZSCORE and NPLR show significant negative relationships with BM. For ZSCORE this means that having stable banks leads to lower levels of financial development. For NPLR this implies that higher NPLs weakens the financial system. Both outcomes are plausible since stable banks mean banks are taking less risk and so the associated rewards are reduced. On the other, higher credit risk retards financial development as it weakens banks. These two outcomes suggest that not all risks aid financial development and so to enhance financial development, the appropriate risks must be taken. 
Table 4. 11 Francophone Regression-BM

\begin{tabular}{|c|c|c|c|c|c|c|}
\hline \multicolumn{4}{|c|}{ Fixed-effects (within) regression } & \multicolumn{3}{|c|}{ Number of obs. $=122$} \\
\hline \multicolumn{4}{|c|}{ Group variable: PANELID } & \multicolumn{3}{|c|}{ Number of groups $=41$} \\
\hline \multicolumn{4}{|c|}{$\begin{array}{l}\text { R-sq.: within }=0.6125 \\
\text { between }=0.0033 \\
\text { overall }=0.0196\end{array}$} & \multicolumn{3}{|c|}{$\begin{array}{l}\text { Obs. per group: } \min =1 \\
\text { Avg. }=3.0 \\
\text { Max. }=10\end{array}$} \\
\hline \multicolumn{4}{|c|}{ Corr.(u_i, Xb) $=-0.7636$} & \multicolumn{3}{|c|}{$\mathrm{F}(10,71)=11.22 \quad$ Prob. $>\mathrm{F}=0.0000$} \\
\hline $\mathrm{BM}$ & Coef. & Std. Err. & $\mathrm{T}$ & $\mathrm{P}>\mathrm{t}$ & \multicolumn{2}{|c|}{ [95\% Conf. Interval] } \\
\hline CR3 & .0220308 & .0686601 & 0.32 & 0.749 & -.1148735 & .1589352 \\
\hline SIZE & 9.438425 & 1.126567 & 8.38 & 0.000 & 7.192114 & 11.68474 \\
\hline FINOP & 4.591289 & 4.251099 & 1.08 & 0.284 & -3.885161 & 13.06774 \\
\hline $\mathrm{EXCH}$ & .0127536 & .0175383 & 0.73 & 0.470 & -.0222169 & .047724 \\
\hline MPR & -.2262368 & .2790567 & -0.81 & 0.420 & -.78266 & .3301863 \\
\hline ROAA & .4239819 & .2574596 & 1.65 & 0.104 & -.089378 & .9373418 \\
\hline CAP & .3940089 & .2415513 & 1.63 & 0.107 & -.0876307 & .8756486 \\
\hline ZSCORE & -.6421199 & .2621383 & -2.45 & 0.017 & -1.164809 & -.119431 \\
\hline LIQ & .0243188 & .0513486 & 0.47 & 0.637 & -.0780674 & .126705 \\
\hline NPLR & -.1697372 & .0652301 & -2.60 & 0.011 & -.2998024 & -.039672 \\
\hline _cons & -83.48063 & 17.73927 & -4.71 & 0.000 & -118.8517 & -48.10953 \\
\hline \multicolumn{7}{|c|}{ F test that all $u_{-} \mathrm{i}=0: \quad \mathrm{F}(40,71)=15.66$} \\
\hline
\end{tabular}

The results of the francophone FDCredit regression is presented in table 4.12. The results show that for francophone countries, competition did not matter for financial development. This can be seen from the p-value of CR3. Size has once again proved a positive and significant relationship with financial development as in all previous regression. It can thus be concluded that the effect of size on financial development is consistent in all six regressions. Financial openness has shown a significant relationship for the first time. The result shows that when the financial openness index increases by one unit, credit to the private sector increased by 9.3 percentage points. Similarly, liquidity shows a significant relationship for the first time. The results also show that banks being more liquid has a positive effect on financial development in francophone countries. 
Table 4. 12Francophone Regression-FDCredit

\begin{tabular}{|c|c|c|c|c|c|c|}
\hline \multicolumn{4}{|c|}{ Fixed-effects (within) regression } & \multicolumn{3}{|c|}{ Number of obs. $=122$} \\
\hline \multicolumn{4}{|c|}{ Group variable: PANELID } & \multicolumn{3}{|c|}{ Number of groups $=41$} \\
\hline \multicolumn{4}{|c|}{$\begin{array}{l}\text { R-sq.: within }=0.6223 \\
\text { between }=0.0124 \\
\text { overall }=0.0171 \\
\end{array}$} & \multicolumn{3}{|c|}{$\begin{array}{ll}\text { Obs. per group: } \min = & 1 \\
\text { Avg. }= & 3.0 \\
\text { Max. }= & 10\end{array}$} \\
\hline \multicolumn{4}{|c|}{ Corr.(u_i, Xb) $=-0.8447$} & \multicolumn{3}{|c|}{$\mathrm{F}(10,71)=11.70$ Prob. $>\mathrm{F}=0.0000$} \\
\hline FDCredit & Coef. & Std. Err. & $\mathrm{t}$ & $\mathrm{P}>\mathrm{t}$ & \multicolumn{2}{|c|}{$[95 \%$ Conf. Interval $]$} \\
\hline CR3 & .0525596 & .0530766 & 0.99 & 0.325 & -.0532721 & .1583914 \\
\hline SIZE & 7.9598 & .8708748 & 9.14 & 0.000 & 6.223325 & 9.696275 \\
\hline FINOP & 9.291523 & 3.286245 & 2.83 & 0.006 & 2.738936 & 15.84411 \\
\hline $\mathrm{EXCH}$ & -.0065522 & .0135577 & -0.48 & 0.630 & -.0335855 & .0204812 \\
\hline MPR & .0799723 & .2157204 & 0.37 & 0.712 & -.3501619 & .5101065 \\
\hline ROAA & .3814397 & .1990251 & 1.92 & 0.059 & -.0154051 & .7782845 \\
\hline CAP & .4679628 & .1867275 & 2.51 & 0.014 & .0956388 & .8402867 \\
\hline ZSCORE & -.6539248 & .2026419 & -3.23 & 0.002 & -1.057981 & -.2498684 \\
\hline LIQ & .0959792 & .0396942 & 2.42 & 0.018 & .0168312 & .1751272 \\
\hline NPLR & -.0070382 & .0504251 & -0.14 & 0.889 & -.107583 & .0935067 \\
\hline _cons & -78.7412 & 13.71306 & -5.74 & 0.000 & -106.0843 & -51.39813 \\
\hline \multicolumn{7}{|c|}{ F-test that all u_i=0: $\quad F(40,71)=12.37$} \\
\hline
\end{tabular}

Capitalization has a positive and significant relationship with financial development, and this means that francophone countries experience higher financial development when the banks are better capitalized. ZSCORE has a negative and significant relationship which is interpreted to mean that when banks are stable on average in francophone countries, there is an adverse impact on the financial development of the countries.

\subsection{Analysis of Results.}

\subsubsection{Bank competition and financial development}

Two variables were used to proxy financial development following the practice by previous authors (Barr, 2005; Ben-Salha \& Jaidi, 2014; Hossain \& Arwatchanakarn, 2017; Levine, 2002; Otchere, Senbet, \& Simbanegavi, 2017). The two variables were the broad money and the ratio of credit-by-financial-institutions (mainly banks)-to-theprivate-sector to GDP (FDCredit).In table 4.7, the regression results showed that there was no significant relationship between broad money and financial development. The results, however, showed a positive coefficient for broad money. In table 4.8 the results show a positive and significant relationship between FDCredit and Financial development.

Generally, the financial sector is said to have developed when the cost of financial intermediation is reduced; when it is easier to enforce financial contracts; and when it is easy to acquire information. Thus, lower costs of financial intermediation such as lower interest rates and bank charges are essential features of financial development. The positive coefficient of CR3 in table 4.8 implies that competition is bad for increasing the credit to the private sector. This is counterintuitive since more competition is expected to cause lower interest rates and increase the amount of credit that is granted. It appears the opposite happens in sub-Saharan Africa. It can be argued that having a few banks dominating the financial sector leads to economies of scale as the banks attract higher numbers of lenders. This may lead to lower per unit cost of lending and thus leading to lower overall cost of credit. Partly also, in the countries with the least competitive sectors, it can be observed that state-owned banks control the sector which could indicate that the government may be giving credit at concessionary rates since governments are motivated less by profits.

In addition to the above, big banks have access to cheaper funds. This could be due to factors such as having more substantial assets to use as collateral and better credibility. Banks usually take time to grow, and so bigger banks are likely to also be among the oldest banks, and this means they have built a strong reputation over the years which will allow them to attract cheaper funds. With the influx of foreign capital into Africa, large banks are more likely 
to receive foreign funds. Thus, it can be argued that having fewer big banks can foster financial development through economies of scale (Blomström, 1986; Tokle et al., 2015).

In a typical country like Ghana, it can be observed while there has been growing competition in the banking sector during the sample period, bigger banks have the lowest interest rates and the larger loan portfolios (Ackah \& Asiamah, 2016; Kusi, Agbloyor, Fiador, \& Osei, 2016; Ladime, Sarpong-Kumankoma, \& Osei, 2013; Nkuah, Tanyeh, \& Gaeten, 2013). The number of banks in Africa has more than doubled in the last decade due to the liberalization of the sector, and this has increased the level of competition in the industry (Ackah \& Asiamah, 2016; Dary \& Issahaku, 2013). However, there still exist differences in the size of the banks such that few large banks have continued to dominate the sector. Though this competition has led to a decline in the interest rates and an increase in the demand (and supply) of credit to the private sector, large banks continue to undercut small banks by offering lower interest rates and this explains why we find a positive relationship between competition and financial development(Delis, 2012; Guevara \& Maudos, 2009; Ladime et al., 2013; Naceur \& Omran, 2011). It is important also to note that, in addition to competition within the sector, banks have also faced competition from savings and loans companies and microfinance institutions and this may have depressed interest rates furtherespecially noting that these non-bank institutions struggle to mobilize cheap funds and are faced with operational inefficiencies associated with being small.

Broad money (BM) on the hand represents the amount of money and money equivalents in circulation at a point in time. On a continent where a high proportion of the residents are unbanked, the amount of money in circulation may not be a good indication of financial development because much of these monies would be held outside the banking system. This could explain why there is no significant relationship between broad money and bank competition.

\subsection{Conclusion and Policy Recommendation}

\subsection{Conclusion}

The study finds that on average $71 \%$ of the banking sector of a typical country in the sample is controlled by three large banks. This was however found to vary widely within the sample, and so the data was split into francophone and Anglophone countries, and it showed that Anglophone countries had a lower concentration ratio of 67\% while francophone countries had a concentration ratio of about $75 \%$. Nigeria had the lowest concentration ratio over the sample period. Banks in Anglophone countries were also found to be bigger on average than their francophone counterparts.

The mean of the exchange rate index was 103.18 over the period for the full sample while anglophone and francophone countries had $96 \%$ and $116 \%$ respectively. The monetary policy rate was about $10 \%$ on average over the period for the full sample and 13\% and 6\% for the anglophone and francophone sample respectively. On average financial institutions extended credit up to $22 \%$ of GDP each year and the broad money supply was $33 \%$ of GDP on average. These stood at $20.5 \%$ and $32.5 \%$ respectively for the francophone sample and $22.5 \%$ and $33.5 \%$ respectively for the Anglophone sample. Banks' return on average assets was about $1.4 \%$ per annum in the full sample, and their ZSCORE was about $12 \%$ on average. Anglophone countries had average gains of 1.9\% compared to $0.91 \%$ francophone countries and a ZSCORE of $12.7 \%$ compared to $13.4 \%$ for francophone countries. The liquidity ratio of banks was $47 \%$, and non-performing loans ratio was $9 \%$ in the full sample. This ratio stood at $46 \%$ and $8.7 \%$ respectively for the Anglophone sample and $48 \%$ and $10.5 \%$ respectively for the francophone sample

The regression results show a positive and significant relationship between financial development (FDCredit) and competition (CR3) for the full sample and the anglophone samples. Bank size affects financial development positively in all samples. Bank profitability impacts positively on financial development in the full sample and the francophone sample. Exchange rate impacts financial development in Anglophone countries. The findings also show that banking sector stability is essential for the financial development of both Anglophone francophone countries. Also, lower NPLs have a positive impact on financial development in francophone countries. Capitalization and liquidity had a positive impact on financial development in francophone countries. 


\subsection{Policy Recommendation}

We recommend that policy should focus on firm-level growth as this is the most pervasive variable in all the results which shows a positive impact on financial development. That is to say, that policy should seek to support individual banks to grow. The findings have shown that having bigger banks leads to economies of scale which will impact positively on financial development.

However, the findings also imply that having too many banks do not augur well for financial development as the majority of the banks tend to be inefficient. Regulators could impose barriers that will restrict entry to the market to ensure that the few strong banks can offer businesses credit at lower rates leading to development in the financial sector. Furthermore, we recommend that for Anglophone countries, less emphasis should be placed on bank-level variables as these do not have significant impacts on the financial sector. Francophone countries should, however, control bank-level variables to ensure that they achieve greater financial development.

Each of the countries included in the study has peculiarities that distinguish them from others; this is obvious in the results presented above. It is recommended that future studies should look more closely at individual countries. Future studies should also explore other bank and macroeconomic variables to understand which of them might explain financial development.

\section{References}

Ackah, C., \& Asiamah, J. P. (2016). Financial regulation in Ghana balancing inclusive growth with financial stability. Achieving Financial Stability and Growth in Africa, (November), 107-121.

Allen, F. \& Gale, D. (2004). Competition and Financial Stability. Journal of Money, Credit, and Banking, 36(3), 453-480

Altunbas, Y., Gambacorta, L., \& Marques-Ibanez, D. (2012). Do bank characteristics influence the effect of monetary policy on bank risk? Economics Letters, 117(1), 220-222.

Angkinand, A., \& Wihlborg, C. (2010). Deposit insurance coverage, ownership, and banks' risk-taking in emerging markets. Journal of International Money and Finance, 29(2), 252-274.

Apanga, M. A. N., Appiah, K. O., \& Arthur, J. (2016). Credit risk management of Ghanaian listed banks. International Journal of Law and Management, 58(2), 162-178.

Apergis, N., \& Christou, C. (2015). The behaviour of the bank lending channel when interest rates approach the zero lower bound: Evidence from quantile regressions. Economic Modelling, 49, 296-307.

Asante, S., Agyapong, D. \& Anokye, M. A. (2011). Bank Competition, Stock Market and Economic Growth in Ghana. International Journal of Business Administration, Sciedu Press, vol. 2(4), 33-41

Barr, M. S. (2005). Microfinance and Financial Development. Michigan Journal of International Law, 26(2000), $271-$ 296.

Barth, J. R., Lin, C., Ma, Y., Seade, J., \& Song, F. M. (2013). Do bank regulation, supervision and monitoring enhance or impede bank efficiency? Journal of Banking and Finance, 37(8), 2879-2892.

Batini, N., \& Turnbull, K. (2002). A dynamic monetary conditions index for the UK. Journal of Policy Modeling, 24(3), 257-281.

Baum, C. F., Schaffer, M. E., \& Stillman, S. (2007). Enhanced routines for instrumental variables/GMM estimation and testing. Stata Journal, 7(4), 465-506.

Beck, T., Chen, T., Lin, C., \& Song, F. M. (2012). Financial Innovation: The Bright and the Dark Sides. Tilburg University Press.

Beck, T., De Jonghe, O., \& Schepens, G. (2013). Bank competition and stability: Cross-country heterogeneity. Journal of Financial Intermediation, 22(2), 218-244.

Behr, P., Foos, D., \& Norden, L. (2017). Cyclicality of SME lending and government involvement in banks. Journal of Banking and Finance, 77, 64-77.

BekmurodovaGo'zal, A. (2016). Banking Competition and Stability. International Journal of Management science and business Administration. 2(6), 26-33.

Ben-Salha, O., \& Jaidi, Z. (2014). Some new evidence on the determinants of money demand in developing countries - A case study of Tunisia. Journal of Economic Asymmetries, 11, 30-45.

Bhagat, S., Bolton, B., \& Lu, J. (2015). Size, leverage, and risk-taking of financial institutions. Journal of Banking and 
Finance, 59, 520-537.

Bjørnland, H. C. (2009). Monetary policy and exchange rate overshooting: Dornbusch was right after all. Journal of International Economics, 79(1), 64-77.

Blomström, M. (1986). Multinationals and market structure in Mexico. World Development, 14(4), 523-530.

Borio, C., \& Gambacorta, L. (2017). Monetary policy and bank lending in a low interest rate environment: Diminishing effectiveness? Journal of Macroeconomics, 54, 1339-1351.

Boudriga, A., Boulila Taktak, N., \& Jellouli, S. (2009). Banking supervision and nonperforming loans: a cross-country analysis. Journal of Financial Economic Policy (Vol. 1).

Brei, M., Gambacorta, L., \& von Peter, G. (2013). Rescue packages and bank lending. Journal of Banking and Finance, 37(2), 490-505.

Cameron, A. C., \& Trivedi, P. K. (2009). Microeconometrics using Stata. Stata Press Books, 5, 706.

Carbó-Valverde, S., Benink, H. A., Berglund, T., \& Wihlborg, C. (2015). Regulatory response to the financial crisis in Europe: recent developments (2010-2013). Journal of Financial Economic Policy, 7(1), 29-50.

Carletti, E. \& Hartmann, P. (2002). Competition and stability: what's special about banking? ECB Working Paper 146. European Central Bank: Frankfurt

Carvallo, O., \& Pagliacci, C. (2016). Macroeconomic shocks, bank stability and the housing market in Venezuela. Emerging Markets Review, 26, 174-196.

Cetorelli, N. \& Peretto, P. F. (2012). Credit quantity and credit quality: bank competition and capital accumulation. Journal of economic theory, 147(3), 967-998.

Cetorelli, N. \&. Strahan, P.E. (2006). Finance as a barrier to entry: Bank Competition and Industry structure in Local U.S Market. Journal of finance, American Finance Association, 61(1), 437-461.

Chadha, J. S., \& Waters, A. (2014). Applying a macro-finance yield curve to UK quantitative Easing. Journal of Banking and Finance, 39(1), 68-86.

Chauvet, L \& Jacolin, L. (2017). Financial Inclusion, Bank Concentration and Firm Performance. World Development, Elsevier, 97(C), 1-13

Chinn, M. D., \& Ito, H. (2008). A New Measure of Financial Openness. Journal of Comparative Policy Analysis, 10(3), $309-322$.

Claessens, S \& Laeven, L. (2005). Financial dependence, banking sector competition and economic growth, Policy Research Working Paper Series 3481, The World Bank.

Dary, S. K., \& Issahaku, H. (2013). Exploring Innovations in Microfinance Institutions in Northern Ghana. Business \& Economic Research (BER), 3(1), 442-460.

Delis, M. D. (2012). Bank competition, fi nancial reform, and institutions : The importance of being developed. Journal of Development Economics, 97(2), 450-465.

Dell'Ariccia, G., Laeven, L., \& Marquez, R. (2014). Real interest rates, leverage, and bank risk-taking. Journal of Economic Theory, 149(1), 65-99.

Demirguc-Kunt, A., Klapper, L., Singer, D \&Oudheusden, P.V. (2015). The Global Findex Database 2014: Measuring Financial Inclusion around the World. Policy Research Working Paper 7255. World Bank, Washington, DC

Dong, Y., Firth, M., Hou, W., \& Yang, W. W. (2014). Evaluating the performance of Chinese commercial banks: a comparative analysis of different types of banks. European Journal of Operational Research, 252, 280-295.

Drukker, D. M. (2003). Testing for serial correlation in linear panel-data models. Stata Journal, 3(2), 168-177.

Eijffinger, S. C. W., \& Karataş, B. (2012). Currency crises and monetary policy: A study on advanced and emerging economies. Journal of International Money and Finance, 31(5), 948-974.

ElBannan, M. A. (2015). Do consolidation and foreign ownership affect bank risk taking in an emerging economy? An empirical investigation. Managerial Finance, 41(9), 874-907.

Fiordelisi, F., Galloppo, G., \& Ricci, O. (2014). The effect of monetary policy interventions on interbank markets, equity indices and G-SIFIs during financial crisis. Journal of Financial Stability, 11(1), 49-61.

Fries, S. and Taci, A. (2005). Cost efficiency of banks in transition: Evidence from 289 banks in 15 post-communist countries. Journal of Banking \& Finance, 29(1), 55-81

Gambacorta, L. (2009). Monetary policy and the risk-taking channel. BIS Quarterly Review, (December), 43-53.

George, G. E., Miroga, J. B., Ngaruiya, N. W., Mindila, R., Nyakwara, S., Mobisa, M. J., ... Moronge, M. O. (2013). An analysis of loan portfolio management on organization profitability : Case of commercial banks in Kenya. Research Journal of Finance and Accounting, 4(8), 24-36.

Giannetti, M. \&Ongena, S. (2005. Financial integration and entrepreneurial activity: evidence 
from foreign bank entry in emerging markets. Working Paper Seriesn498, European Central Bank.

Guevara, J. F. De, \& Maudos, J. (2009). Regional Financial Development and Bank Competition : Effects on Firms ' Growth. Regional Studies, 43(2), 211-228.

Hakenes, H., \& Schnabel, I. (2011). Capital regulation, bank competition, and financial stability. Economics Letters, 113(3), 256-258.

Hasan, I. \& Marton, K. (2001). Development and efficiency of the banking sector in a transnational economy: Hungarian experience. Journal of banking \& finance, Elsevier, 27(12)

Hassan, R., \& Shahzad, M. M. (2011). A macroeconometric framework for monetary policy evaluation: A case study of Pakistan. Economic Modelling, 28(1-2), 118-137.

Hegre, H., Oneal, J. R., \& Russett, B. (2010). Trade does promote peace: New simultaneous estimates of the reciprocal effects of trade and conflict. Journal of Peace Research, 47(6), 763-774.

Hossain, A. A., \& Arwatchanakarn, P. (2017). Does Money Have a Role in Monetary Policy for Price Stability under Inflation Targeting in Thailand? Journal of Asian Economics, 53, 37-55.

Iannotta, G., Nocera, G., \& Sironi, A. (2007). Ownership structure, risk and performance in the European banking industry. Journal of Banking and Finance, 31(7), 2127-2149.

Ivanovic, M. (2016). Determinants of credit growth: The case of Montenegro. Journal of Central Banking Theory and Practice, 5(2), 101-118.

King, R. G., \& Levine, R. (1993). Finance and Growth : Schumpeter Might be Right. Oxford Journals, 108(3), 717 737.

King, R.G. and Levine, R. (1993b). - Finance and Growth: Views and Agendall. Journal of Economic Literature, 35, 688-726

Kuranchie-Pong, L., Bokpin, G. A., \& Andoh, C. (2016). Empirical evidence on disclosure and risk-taking of banks in Ghana. Journal of Financial Regulation and Compliance, 24(2), 197-212.

Kusi, B. A., Agbloyor, E. K., Fiador, V. O., \& Osei, K. A. (2016). Does Information Sharing Promote or Detract from Bank Returns: Evidence from Ghana. African Development Review, 28(3), 332-343.

Ladime, J., Sarpong-Kumankoma, E., \& Osei, K. A. (2013). Determinants of Bank Lending Behaviour in Ghana. Journal of Economics and Sustainable Development, 4(17), 42-47. Retrieved from www.iiste.org

Laeven, L., Levine, R., \& Michalopoulos, S. (2015). Financial innovation and endogenous growth. Journal of Financial Intermediation, 24(1), 71-88.

Levine et al. (2000). Financial intermediation and economic growth: Causes and causality. Journal of Monetary Economics, 46, 31-77.

Levine, R., \& Zervos, S. (1998). Stock Markets, Banks, and Economic Growth. American Economic Review, 88, 537558.

Lafourcade, A., Isern, J., Mwangi, P., \& Brown, M. (2006). Overview of the Outreach and Financial Performance of Microfinance Institutions in Africa. Microbanking Bulletin, (April), 3-14.

Law, S.H \& Singh, N. (2014). Does too much finance harm economic growth? Journal of Banking and Finance, 41, 36-44

Leon, F. (2015). Does bank competition alleviate credit constraint in developing countries? Journal of Banking and Finance, 57, 130-142

Levine, R. (2002). Bank-based or market-based financial systems: Which is better? Journal of Financial Intermediation, 11(4), 398-428.

Levine, R. (2004). Finance and Growth: Theory and Evidence. NBER Working Paper Series, (September).

Li, J., Hsu, S., \& Qin, Y. (2014). Shadow banking in China: Institutional risks. China Economic Review, 31(71173246), $119-129$.

Lyons, S. E., \& Murinde, V. (1994). Cointegrated and Granger causality testing of hypothesis on supply leading and demand following finance, Economic Note, 23, 17-36

Manove, M., Padilla, A. J., \& Pagano, M. (2001). Collateral versus project screening: A model of lazy banks. Rand journal of economics, 726-744

Maredza, A. (2015). The Trade-Off Between Banking Outreach And Profitability : Evidence from Selected Southern African Development Community Countries. The Journal of Interntional Business and Economics Research Journal, 14(1), 55-66.

Mayordomo, S., \& Rodríguez-Moreno, M. (2018). Did the bank capital relief induced by the Supporting Factor enhance SME lending? Journal of Financial Intermediation, (August 2017), 1-13.

Mitchener, K. J. \& Wheelock, D. C., (2013). Does the structure of banking markets affect? 
economic growth? Evidence from U.S state banking markets. Explorations in Economic History. Elsevier 50(2), $161-178$

Murinde, V. \&Eng, F.S.H (1994). Financial Development and Economic Growth in Singapore:

Demand Following or Supply-Leading? Applied Financial Economics, 4, 391-404.

Naceur, S. Ben, \& Omran, M. (2011). The effects of bank regulations, competition, and financial reforms on banks' performance. Emerging Markets Review, 12(1), 1-20.

Ncube, M. (2007). Financial Services and Economic Development in Africa. Journal of African

Economies, 16(1), 3-57

Ngongang, E. (2015). Financial Development and Economic Growth in Sub- Saharan n Africa: A

Dynamic Panel Data Analysis. European Journal of Sustainable Development, 4(2), 369-378

Nkuah, J. K., Tanyeh, J. P., \& Gaeten, K. (2013). Financing small and medium enterprises (SMES) in Ghana: Challenges and determinants in accessing bank credit. International Journal of Research In Social Sciences, 2(3), 12 25.

Odhiambo, N. (2004). Money and Physical capital are complementary in Kenya. International Economic Journal, Taylor \& Francis Journals, 18(1), 65-78.

Otchere, I., Senbet, L., \& Simbanegavi, W. (2017). Financial sector development in Africa - An overview. Review of Development Finance, 7(1), 1-5.

Owen, A. L., \& Pereira, J. M. (2018). Bank concentration, competition, and financial inclusion. Review of Development Finance, 8(1), 1-17.

Partachi, I., \& Mija, S. (2015). Monetary Policy - Instrument for Macroeconomic Stabilization. Procedia Economics and Finance, 20(15), 485-493.

Porzio, C., Sampagnaro, G., \& Verdoliva, V. (2018). Lost in Translation: The determinants and the effect of soft information dispersion in bank lending. Global Finance Journal, (September 2017).

Pruteanu-Podpiera, A., Weill, L. \& Schobert, F (2007). Market power and efficiency in Czech Banking sector. Working papers 2007/6, Czech national bank.

Quartey, P., \& Afful-Mensah, G. (2014). Financial and monetary policies in Ghana: A review of recent trends. Review of Development Finance, 4(2), 115-125.

Quaye, I., Abrokwah, E., Sarbah, A., \& Osei, J. Y. (2014). Bridging the SME Financing Gap in Ghana: The Role of Microfinance Institutions. Open Journal of Business and Management, 2(October), 339-353.

Rasche, R. H., \& Williams, M. M. (2007). The effectiveness of monetary policy. Federal Reserve Bank of St. Louis Review, 89(5), 447-489.

Roodman, D. (2009). Practitioners' corner: A note on the theme of too many instruments. Oxford Bulletin of Economics and Statistics, 71(1), 135-158.

Sarkar, S., \& Sensarma, R. (2016). The relationship between competition and risk-taking behaviour of Indian banks. Journal of Financial Economic Policy, 8(1), 95-119.

Shen, Y., Shen, M., Xu, Z., \& Bai, Y. (2009). Bank Size and Small- and Medium-sized Enterprise (SME) Lending: Evidence from China. World Development, 37(4), 800-811.

Tchamyou, V. S., \& Asongu, S. A. (2017). Information Sharing and Financial Sector Development in Africa. Journal of African Business, 18(1), 24-49.

Tokle, R. J., Fullerton, T. M., \& Walke, A. G. (2015). Credit union loan rate determinants following the 2008 financial crisis. Social Science Journal, 52(3), 364-373.

Were, M., \& Wambua, J. (2014). What factors drive interest rate spread of commercial banks? Empirical evidence from Kenya. Review of Development Finance, 4(2), 73-82.

World Bank, 2015. SME finance in Ethiopia: Addressing the missing middle challenge. Washington, DC: World Bank Group

Zhuang, J., Gunatilake, H., Niimi, Y., Khan, M. E., Jiang, Y., Hasan, R., ... Huang, B. (2009). Financial sector development, economic growth, and poverty reduction: A literature review. ADB Economics Working Paper Series, 173(173), 1-48.

Zulkhibri, M. (2015). Interest burden and external finance choices in emerging markets: Firm-level data evidence from Malaysia. International Economics, 141, 15-33. 